\title{
Determination of Optimum Hot-Water Temperatures for PCM Radiant Floor-Heating Systems Based on the Wet Construction Method
}

\author{
Sanghoon Baek ${ }^{1}$ (D) and Sangchul Kim ${ }^{2, *}$ \\ 1 Industry Academic Cooperation Foundation, Hankyong National University, \\ 327, Jungang-ro, Anseong-si, Gyeonggi-do 17579, Korea; shbaek2018@gmail.com \\ 2 School of Architecture, Hankyong National University, \\ 327, Jungang-ro, Anseong-si, Gyeonggi-do 17579, Korea \\ * Correspondence: sckim08@hknu.ac.kr; Tel.: +82-31-670-5277
}

Received: 6 September 2018; Accepted: 27 October 2018; Published: 1 November 2018

\begin{abstract}
Owing to use of mortar, which demonstrates low heat storage and discharge performance, conventional radiant floor-heating systems, based on the wet construction method and hot-water circulation, consume large amounts of energy. This study proposes a new type of radiant floor-heating system that is capable of reducing energy consumption via use of the latent heat of a phase change material (PCM), whereby the phase change, which occurs within, is induced by the thermal energy supplied by hot water. Simulation analyses revealed that hot-water supply temperatures, required to maintain the floor-surface and indoor-air temperatures at the set point using PCM latent heat, were in the range $40-41{ }^{\circ} \mathrm{C}$. At supply water temperatures measuring less than $39^{\circ} \mathrm{C}$ or exceeding $42{ }^{\circ} \mathrm{C}$, the latent-heat effect of the phase change of the PCM tended to fail, and the corresponding floor-surface temperature assumed a value different from that corresponding to the set point. By contrast, supply temperatures in the range $40-41{ }^{\circ} \mathrm{C}$ resulted in return temperatures measuring approximately $27.4-27.5^{\circ} \mathrm{C}$, which in turn corresponded to an indoor air temperature of $21.6-22.6^{\circ} \mathrm{C}$ that was stably maintained within $\pm 0.6^{\circ} \mathrm{C}$ of the $22{ }^{\circ} \mathrm{C}$ set-point temperature.
\end{abstract}

Keywords: PCM radiant floor-heating system; wet construction method; hot-water temperature; apartment housing

\section{Introduction}

Nearly all materials undergo transition from one state (solid, liquid, or gas) to another via absorption or discharge of heat, and depending upon which state they lie in, with respect to their particular phase-change points (e.g., melting and boiling points), most substances undergo sensible or latent heat exchange [1]. During sensible heat exchange, which for liquid water occurs in the temperature range $0-100^{\circ} \mathrm{C}$, only the temperature of a substance changes, and no change occurs in its state. In contrast, during latent heat exchange, such as the transition from ice to water at $0{ }^{\circ} \mathrm{C}$, the material state of a substance changes isothermally (at the same temperature). Most materials absorb and discharge more heat during latent heat exchange compared to sensible heat exchange, and if a material continues to demonstrate latent heat exchange for a sufficient length of time, it can be used as a system for storing and supplying large quantities of heat.

Representative materials that demonstrate rather long latent heat exchange durations are referred to as phase change materials (PCMs). PCMs not only demonstrate extended durations of latent heat exchange during phase change, they are also capable of storing and discharging large quantities of heat in an isothermal manner. These materials are now being used in buildings as heat storage and discharge reservoirs for radiant floor-heating systems. Replacing conventional floor-heat-storage 
materials, which only demonstrate sensible heat exchange, with PCM enables radiant floor-heating systems to maintain indoor-air and floor-surface temperatures at a pre-set value without activating the heat-source system, thereby significantly reducing the energy consumed by the overall system. Many studies concerning PCM radiant floor-heating systems have been performed in recent times to explore appropriate PCM container shapes for floor insertion, and it has been demonstrated that use of a PCM can result in significant benefits in terms of reduced indoor-air and floor-surface temperature maintenance and increased energy savings.

Lin et al. proposed an underfloor electric heating system with SSPCM (shape-stabilized PCM) based on a dry construction method, and analyzed its thermal storage and heating energy performance [2]. In addition, utilizing a SSPCM, they developed a floor heating system using a conductive heat transfer method to decrease heating energy usage in an office space, and evaluated its energy saving performance [3]. Jin et al. proposed a floor radiant cooling and heating system based on a concrete structure with both low-temperature and high-temperature PCMs, and analyzed its thermal storage and energy saving via experimental tests [4]. Huang et al. proposed a hybrid PCM floor heating system, which integrated a PCM floor structure and a solar hot water system, and evaluated its energy performance through experimental tests [5]. Barzin et al. developed a PCM wallboard for underfloor heating and analyzed its energy saving performance via experimental tests [6]. Cheng et al. fabricated SSPCMs with various thermal conductivities for an underfloor heating system, and found, experimentally, that conductivities influence the thermal storage and energy performances of PCM [7]. Zhou et al. analyzed changes in thermal storage and energy performance by types of thermal storage masses and electric supply systems in a PCM radiant floor heating system [8]. Maria et al. proposed an underfloor heating system integrating PCM and a solar system with a heat pump, and evaluated its effects for reducing heating loads and energy consumptions [9].

Extant studies have focused on the use of PCM systems with dry-constructed floor structures that use electricity as a heat source. However, there has been a complete lack of research concerning the integration of PCMs with concrete-based wet-constructed floor structures that employ hot water as the heat source. Although wet-constructed structures provide high floor strength and serve to improve structural stability and the comfort of residents, owing to the lack of air cavities that generate noise or induce dew condensation [10], such structures consume large amounts of hot water and energy to maintain indoor-air and floor-surface temperatures at a pre-set value during the heating period. This may be attributed to their use of mortar, which only demonstrates sensible heat exchange, as the heat-storage material [11]. Using PCMs with long latent-heat exchange durations can, therefore, reduce the energy consumption of wet-constructed structures whilst also maintaining indoor-air and floor-surface temperatures at a pre-set value.

The authors have previously proposed a PCM radiant floor-heating system-built using the wet construction method and employing hot-water circulation-which could potentially form the middle-story of an apartment house. In the proposed and extant studies, the authors propose a design and system structure and describe methods for constructing a PCM container. In addition, the range of PCM melting-point temperatures required to maintain comfortable indoor-air and floor-surface temperatures has also been calculated [12-14].

However, because floors between stories in an apartment housing must meet basic, legally prescribed performance requirements in terms of noise transmission between stories, waterproofing, and structural safety $[15,16]$, it is, in practice, nearly impossible to completely change an existing floor structure to insert PCMs. For this reason, it is more effective to replace part of the existing floor material and subsequently employ the reheating storage method, wherein the heat storage and discharge cycles of PCMs are repeated via circulation of hot water during heating periods. In this case, the hot water for floor heating must have appropriate supply and return temperatures, to maintain the floor-surface and indoor-air temperatures at the pre-set value, while PCM undergoes phase change during the heating period. If the temperature of the supplied hot water is too high, the PCM would enter a superheated state and liquefy, thereby resulting in an increase in the temperature of the PCM 
as well as the floor surface and indoor air, which in turn would lead to occupant discomfort and increased energy consumption. On the other hand, if the temperature of the supplied hot water is too low, the PCM would remain in the supercooled solid state and, if the PCM does not undergo a phase change, the pre-set temperature will not be attained and the reduction in energy consumption through the utilization of latent heat will not be realized. To solve these problems whilst efficiently running the PCM radiant floor-heating system, it is necessary to derive optimum values of hot-water supply and return temperatures.

Accordingly, the goal of this study was to determine appropriate hot-water supply and return temperatures, for the maintenance of floor-surface and indoor-air temperatures at the pre-set value, by use of a PCM radiant floor-heating system fabricated using the wet construction method. These parameters were derived using computer simulation of a residential building under pre-set indoor and outdoor environmental conditions.

\section{Materials and Methods}

\subsection{Materials}

\subsubsection{System Structure and Characteristics}

Because the PCM radiant floor-heating system proposed in this study was designed to be used in intermediate floors of domestic apartment-type housing structures, domestic floor-structure standards were applied in its construction $[15,17]$. The design and structure of the system could; however, be changed depending on the place of residence to reflect varying architectural cultures and structural standards.

The (a) panel in Figure 1 depicts the floor structure commonly used in domestic apartment-type housing, which is constructed in the following sequence of structural layers stacked over one another: $210 \mathrm{~mm}$ concrete slab; $20 \mathrm{~mm}$ insulating material; $40 \mathrm{~mm}$ autoclaved lightweight concrete (ALC); $40 \mathrm{~mm}$ mortar, including a hot-water pipe with a typical inner diameter measuring 15-20 mm [18]; and finally, floor-finishing material. Because the floor-finishing material is excluded from domestic structural standards, a prospective client may select it in accordance with desired floor characteristics. In such systems, mortar is used to facilitate heating via storage and discharge of thermal energy from hot water. However, because mortar only demonstrates sensible heat exchange, wherein temperature changes occur without any phase change, its surface temperature decreases rapidly once hot-water supply is terminated. Accordingly, conventional systems require a continuous supply of hot water to maintain the floor-surface temperature at the pre-set value, whilst consuming large quantities of energy owing to long operation times of the heat-source system.

The (b) panel in Figure 1 depicts a schematic of the proposed radiant floor-heating system, wherein a PCM is inserted into an existing floor system that demonstrates sensible as well as latent heat exchanges [13]. Because this system can maintain the floor-surface and indoor-air temperatures at a pre-set value via the supply of isothermal energy from PCM, without the need for continuous hot-water supply, energy consumption can be reduced through intermittent operation of the heat-source system.
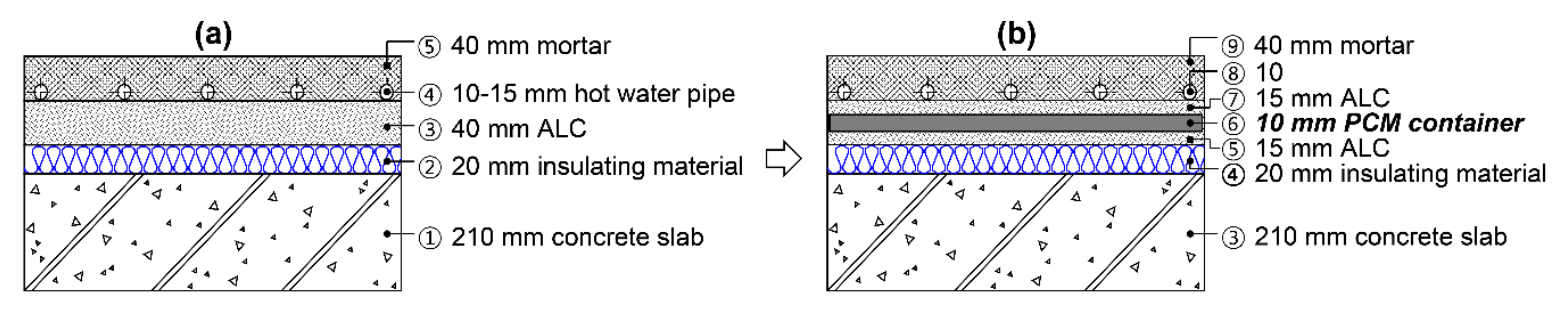

Figure 1. Structures of conventional (a) and phase change material (PCM) (b) radiant floor-heating systems. ALC: Autoclaved lightweight concrete. 
PCM can be inserted into the ALC and mortar layers of an existing floor structure without manipulating the concrete slab, which performs a structural and insulating function, material for preventing heat loss from the floor. Insertion of PCM into mortar can cause several problems. First, as depicted in Figure 2a, the mortar layer includes a $15-20 \mathrm{~mm}$ diameter hot-water pipe, above which PCM must be inserted. If, for example, a $10 \mathrm{~mm}$ thick PCM is to be inserted, the thickness of the top mortar layer would be reduced to $10-15 \mathrm{~mm}$. Since such thinning of the mortar layer would lead to crack formation on the floor surface, additional mortar would have to be applied, which in turn would reduce the ceiling height as well as the volume of the indoor space, thereby lowering the value and selling price of the building. This effect would be particularly seen in construction markets, such as South Korea, wherein the ceiling height and indoor volume are considered sensitive factors.

Although methods exist for reducing ceiling space-for duct and electric works—which could be used to restore the original ceiling height, following mortar thickening to accommodate a PCM (panel (b) of Figure 2), reducing the ceiling working space can have significant effects on both duct and electric works. This, in turn, could lead to cascading effects, wherein all plans related to building heating, ventilation, and air-conditioning (HVAC) would have to be amended. For these reasons, the proposed method avoids PCM insertion into the mortar layer.

(a)

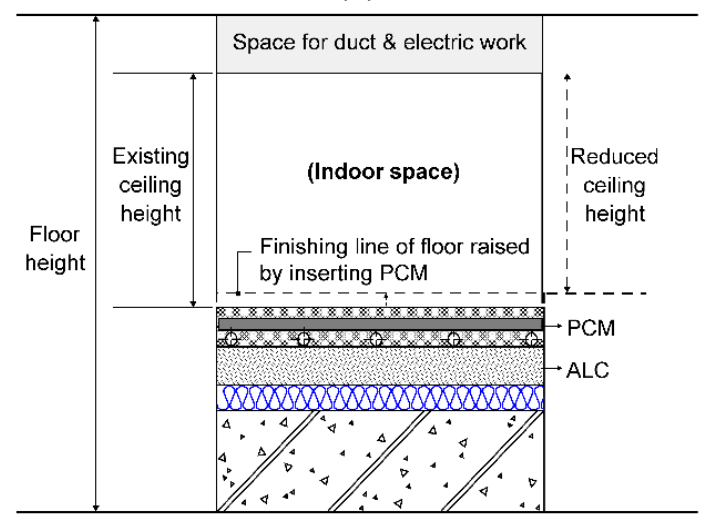

(b)

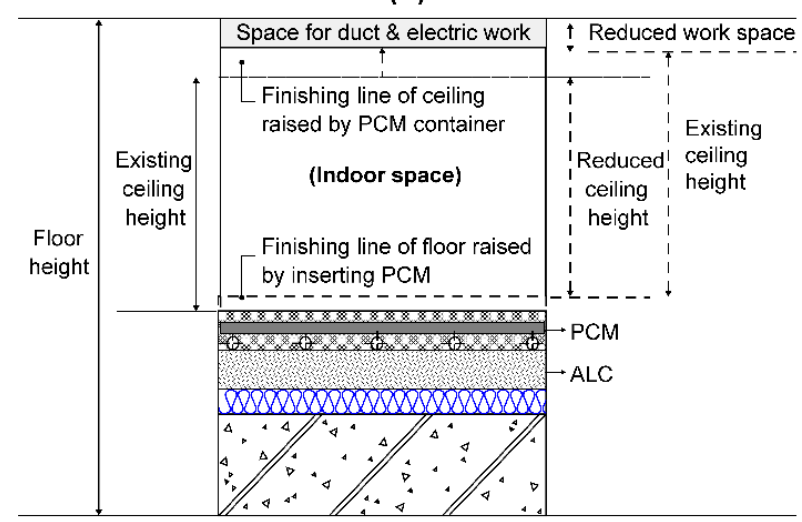

Figure 2. Indoor (a) and ceiling (b) space reduction owing to PCM insertion.

Although ALC prevents heat loss from a floor, its practical role is to mitigate noise transmission between stories. According to recent studies; however, commonly used ALC materials demonstrate a rather poor noise abatement performance owing to their low density, and new systems to replace it are, therefore, being actively developed [19-22]. As an added advantage, PCMs can absorb noise more effectively, compared to conventional ALC materials, owing to their very high densities and the fact that they enter an intermediate state, between solid and liquid, during phase change. The possibility of using PCM as a floor material to replace ALC inspired our placement of PCM into the ALC layer in the proposed system (see Figure 1).

PCM used in the proposed system measured $10 \mathrm{~mm}$ thick. Because heat storage and discharge capability increased with the amount of PCM inserted, it was advantageous, from the point of view of energy saving, to insert as much PCM as possible into the floor, thereby replacing as much ALC as possible with PCM. Since preventing noise transmission is also a critical function of intermediate floors in an apartment-type housing, further experimental research to obtain quantitative data concerning the soundproofing effect of PCM must be performed. However, as this study primarily focused on the reduction of energy consumption in indoor environments, a set PCM thickness of $10 \mathrm{~mm}$ was used in anticipation of future research concerning the soundproofing effects of the proposed system.

\subsubsection{PCM Aluminum Container}

Prior to PCM insertion into a floor structure, it must be contained within a structure inside which it could safely undergo phase change from solid to liquid. Figure 3 depicts a PCM container fabricated 
for use in an extant study and its construction process [13]. Given the high thermal conductivity and durability of the floor, the container was fabricated using a thin aluminum sheet to accommodate the $10 \mathrm{~mm}$ thick PCM, specified in Section 2.1.1. The aluminum container used was slightly irregular in terms of thickness, owing to it being constructed using vacuum equipment and the application of a superheated hot wire for use in a previous floor-heating-module investigation. Such irregularities could be avoided in future construction of the container through use of an automated system for its fabrication [23].

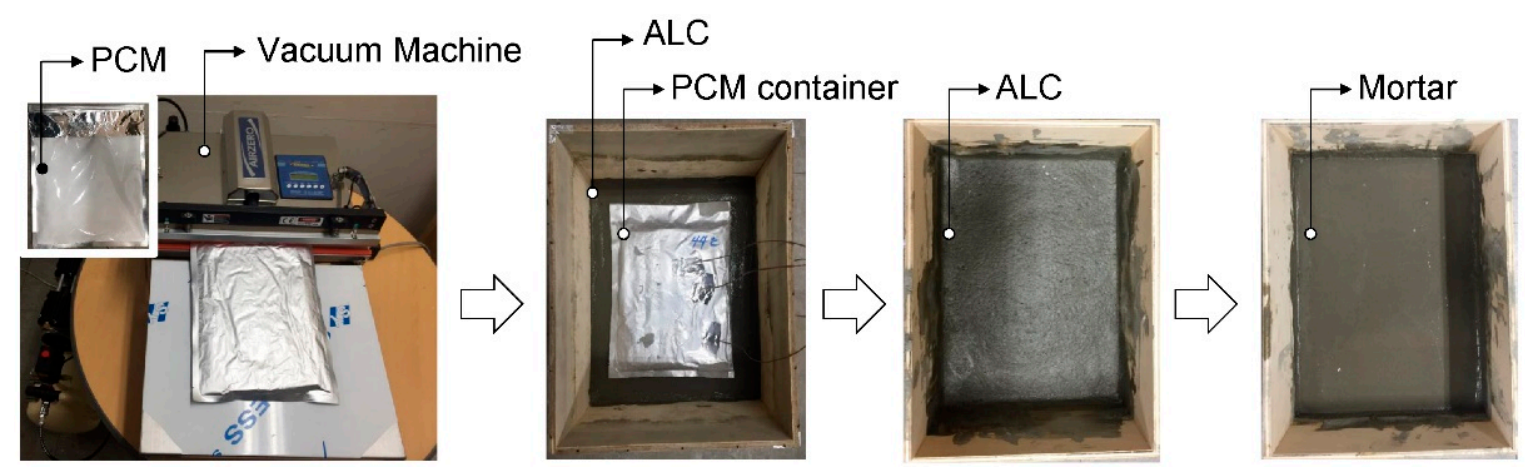

Figure 3. Fabrication and construction of the aluminum container for the PCM.

\subsubsection{Surface Temperature and Energy-Consumption Pattern}

Figures 4 and 5, respectively, demonstrate indicative patterns of floor-surface temperature change in the use of conventional and PCM radiant floor-heating systems, installed in apartment-type housing facilities.

Following preheating, to increase the natural floor-surface temperature from its value at the beginning of the heating period to its pre-set value, the surface temperature of the conventional system follows a sawtooth sinewave pattern, between the top $(+)$ and bottom $(-)$ of the error range of the pre-set floor temperature. If the surface temperature attains the value corresponding to the top or bottom of the error range, the hot-water supply must be stopped or restarted, respectively. This is problematic from the perspective of energy utilization, because the time taken to transit from the top to the bottom of the range is very short, thereby resulting in repeated cycles of hot-water supply and increased energy consumption.

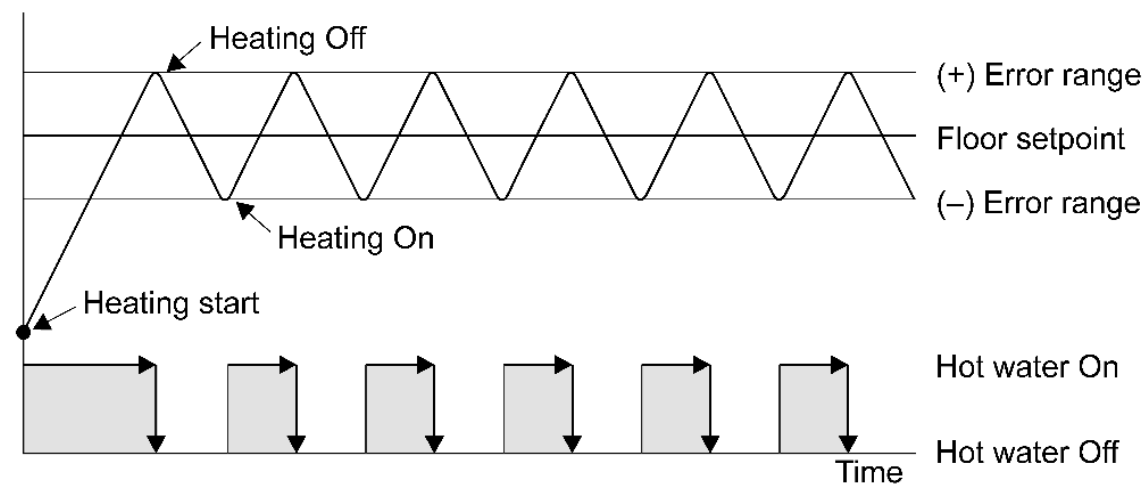

Figure 4. Surface temperature (top) and hot-water supply (bottom) patterns corresponding to the conventional radiant floor-heating system.

In contrast, owing to the thermal energy discharge facilitated by the PCM's latent heat exchange, the floor-surface temperature during use of the PCM radiant floor-heating system could be maintained at the pre-set for a sufficient time after the hot-water supply has been turned off. Through this time-lag phenomenon, surface-temperature decrease is delayed relative to the conventional system, and the reoperation time is, therefore, extended via the latent heat exchange of the PCM. Furthermore, 
as demonstrated by previous small-module experiments, PCM also demonstrates better sensible-heat storage and discharge performance compared to mortar [13], and therefore, even after the latent heat has been discharged, the surface temperature decreases more slowly, when compared to a conventional system, through loss of sensible heat. These features allow the PCM radiant floor-heating system to be operated intermittently whilst suppressing the rapid reduction in floor-surface temperature, thereby reducing hot water as well as energy consumption.

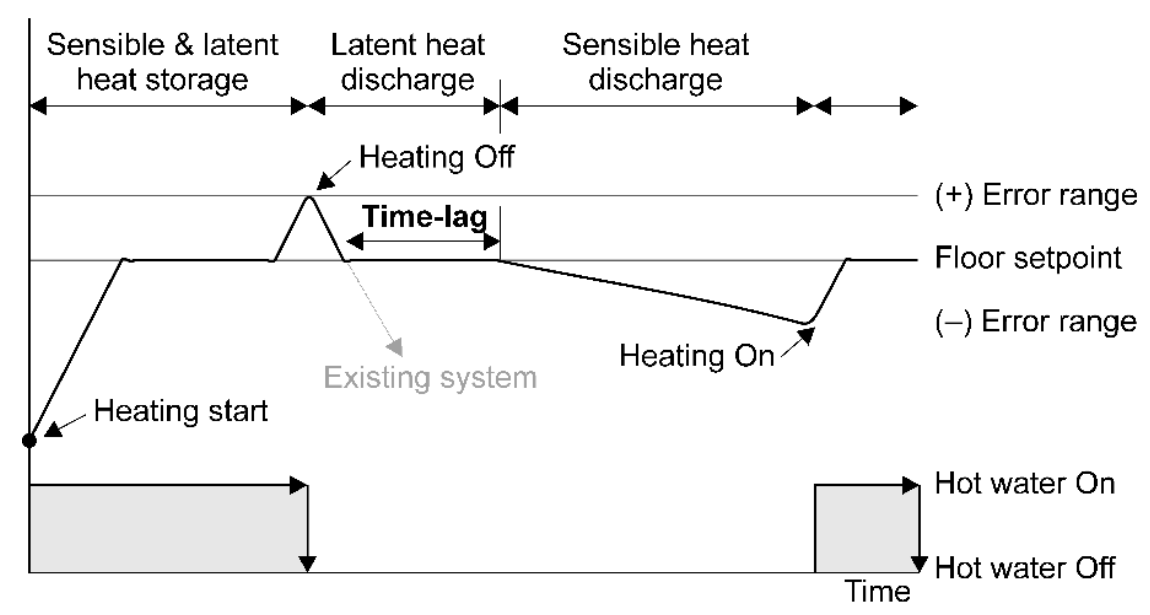

Figure 5. Surface temperature (top) and hot-water supply (bottom) patterns corresponding to the PCM radiant floor-heating system.

\subsection{Methods}

Supply and return temperatures of hot water, used as the heat source in PCM radiant floor-heating systems, must be set to maintain the floor-surface and indoor-air temperatures at the pre-set value during times of minimal annual outdoor temperature [24,25]. To derive appropriate hot water temperatures, the EnergyPlus (ver. 8.7) computer simulation package was used [26-28]. System modeling was performed in the following sequence: (1) Application of weather data; (2) building modeling; (3) composition of envelope and windows; (4) PCM application; (5) input of indoor heat gain and loss elements; (6) application of heating system; and (7) input of heating operation conditions.

\subsubsection{Weather Data}

Table 1 lists details concerning the siting and weather corresponding to the simulated apartment-type housing, which was assumed to be located in Seoul, South Korea. Using standard weather data for Seoul distributed by the government [29], the period from January 26 to 28 - the coldest days of the year-was simulated.

Table 1. Location of simulation building and weather data type. EPW: EnergyPlus Weather.

\begin{tabular}{ccc}
\hline Field & \multicolumn{2}{c}{ Input Value } \\
\hline Site location & Seoul, Korea \\
Building location & Latitude & 37.34 \\
Run period & Longitude & 126.57 \\
Weather date & From January 26 to January 28 \\
\hline
\end{tabular}

Standard weather data, with regards to dry bulb temperature, absolute humidity, wind speed, and solar radiation (Figure 6), were used to calculate the building heating load. For compatibility with EnergyPlus, data were input into the program in the form of a text-based EnergyPlus Weather (EPW) file [27]. 

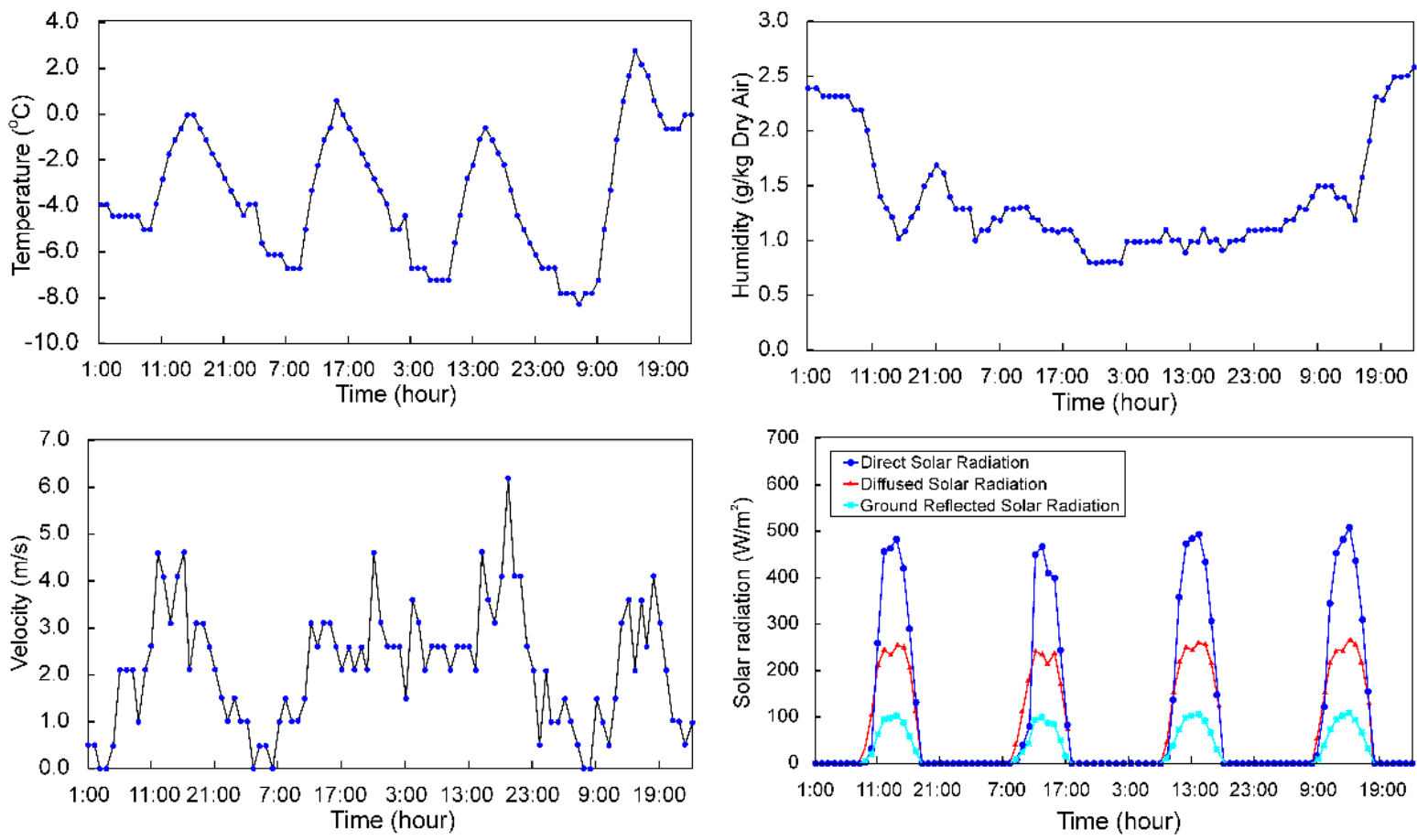

Figure 6. Hourly outdoor weather data.

\subsubsection{Building Modeling}

Figure 7 shows plan and front views of the apartment-type housing and the elevation view modeled via simulation. The building was modeled as a three-story structure with a total height of $8400 \mathrm{~mm}$, including the lowest, middle (standard), and top stories. Each story measured 10,290 $\mathrm{mm}$ in length, 10,530 $\mathrm{mm}$ in width, and $2800 \mathrm{~mm}$ in height. Because the PCM radiant floor-heating system, proposed for use in this study, is to be installed in the middle story of a building, the second story of the modeled building was considered as the analysis target. Indoor space within the building was divided into eight zones, with each zone assumed to be heated simultaneously under identical temperature conditions. Public spaces, such as elevators and stairs, were excluded from the modeling, and windows of different sizes were installed on the south wall.

\subsubsection{Building Structure}

The apartment housing envelope comprised an exterior wall, lowest-story floor structure, middle-story floor structure, and top-story roof. Structural components listed in Table 2 were constructed using eight different types of materials, including the PCM. Material names and their corresponding thermal-property values, including heat conductivity, density, and specific heat, were provided as input into EnergyPlus.

Table 2. Materials comprising the building envelope [30].

\begin{tabular}{|c|c|c|c|c|}
\hline \multicolumn{2}{|r|}{ Field } & \multicolumn{3}{|c|}{ Input Value } \\
\hline \multirow{2}{*}{ No. } & \multirow{2}{*}{ Structural Element } & Conductivity & Density & Specific Heat \\
\hline & & $\left(\mathrm{W} / \mathrm{m} \cdot{ }^{\circ} \mathrm{C}\right)$ & $\left(\mathrm{kg} / \mathrm{m}^{3}\right)$ & $\left(\mathrm{J} / \mathrm{kg} \cdot{ }^{\circ} \mathrm{C}\right)$ \\
\hline 1 & Reinforced concrete & 1.400 & 2300 & 880 \\
\hline 2 & Autoclaved lightweight concrete (ACL) & 0.150 & 710 & 1130 \\
\hline 3 & Mortar & 0.720 & 1860 & 780 \\
\hline 4 & Insulating material & 0.025 & 29 & 1213 \\
\hline 5 & Gypsum board & 0.170 & 800 & 100 \\
\hline 6 & Air cavity & 0.020 & 1.2 & 100 \\
\hline 7 & Phase change material (PCM) & 0.200 & 860 & 2000 \\
\hline 8 & Finishing material & 0.160 & 780 & 1255 \\
\hline
\end{tabular}



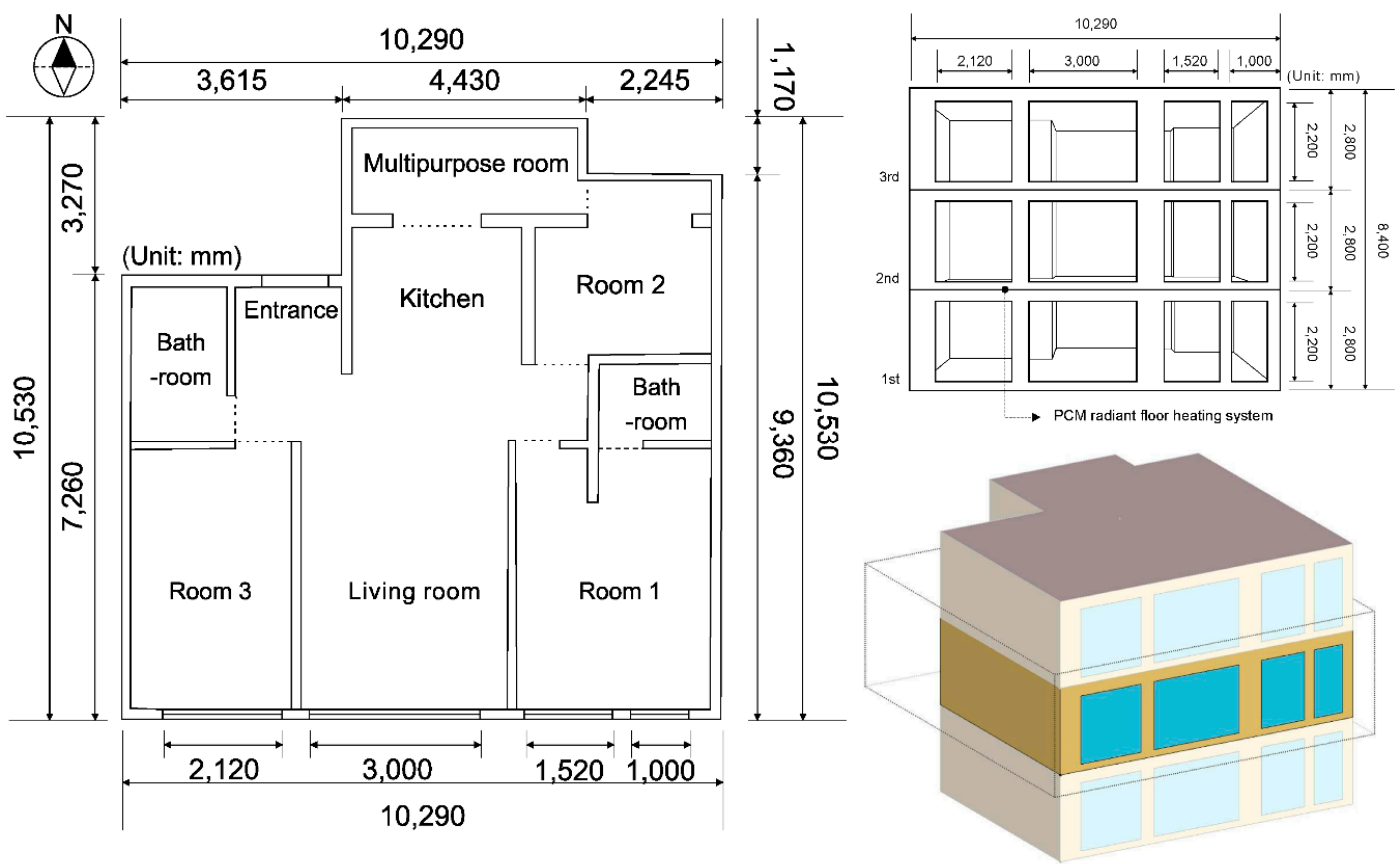

Figure 7. Plan, front, and elevation views of the modeled building.

Figure 8 depicts the envelope structures for the first, second, and third floors, the roof, and the outer wall of the building. The second floor (middle story) was equipped with the PCM radiant floor-heating system, which, along with the third-story floor, included a space for duct and electrical works below the concrete slab. The heat transmittance (U-value) of each envelope (Table 3) was modeled to meet domestic standards [31].
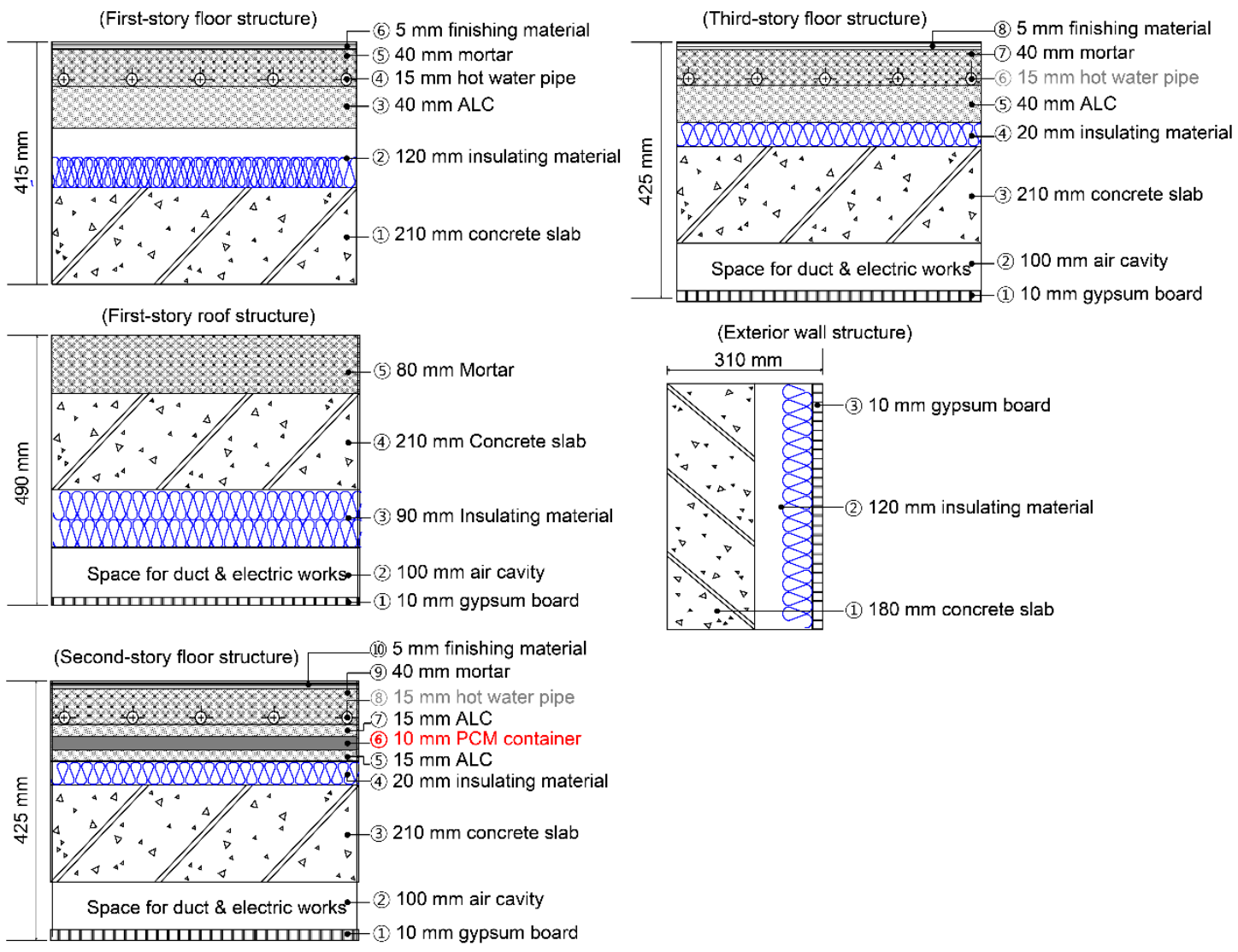

Figure 8. Structures of the building envelopes. 
Table 3. Heat transmittance by envelope type (U-value).

\begin{tabular}{|c|c|c|}
\hline \multirow[t]{2}{*}{ Envelope Type } & $\begin{array}{c}\text { Heat Transmittance } \\
\text { (U-Value) }\end{array}$ & $\begin{array}{c}\text { Domestic Standard } \\
\text { (U-Value) }\end{array}$ \\
\hline & $\left(\mathrm{W} / \mathrm{m}^{2} \cdot{ }^{\circ} \mathrm{C}\right)$ & $\left(\mathrm{W} / \mathrm{m}^{2} \cdot{ }^{\circ} \mathrm{C}\right)$ \\
\hline Floor structure of 1st story & 0.1741 & Below 0.1800 \\
\hline Floor structure of 2nd story (PCM) & 0.1534 & Below 0.8100 \\
\hline Floor structure of 3rd story & 0.1530 & Below 0.8100 \\
\hline Roof structure of 3rd story & 0.1105 & Below 0.1500 \\
\hline Exterior wall structure & 0.2005 & Below 0.2100 \\
\hline
\end{tabular}

To model building windows, data concerning window materials distributed by the Lawrence Berkeley National Laboratory were used along with the Therm and Window simulation program [32,33]. To meet domestic standards for U-values, windows were constructed comprising three panes.

Table 4 lists types and properties of panes, insulating gases, and frames comprising the triple-pane windows considered in this study. The panes measured $6 \mathrm{~mm}$ thick and possessed identical solar-radiation properties on their respective front and back surfaces. The insulating-gas used was $100 \%$ pure argon gas confined to a $12 \mathrm{~mm}$ thickness. The $300 \mathrm{~mm}$ thick frame was made of polyvinyl chloride (PVC) and was injected with urethane to minimize heat loss.

Table 4. Properties of the pane, insulating-gas, and frame for the window system.

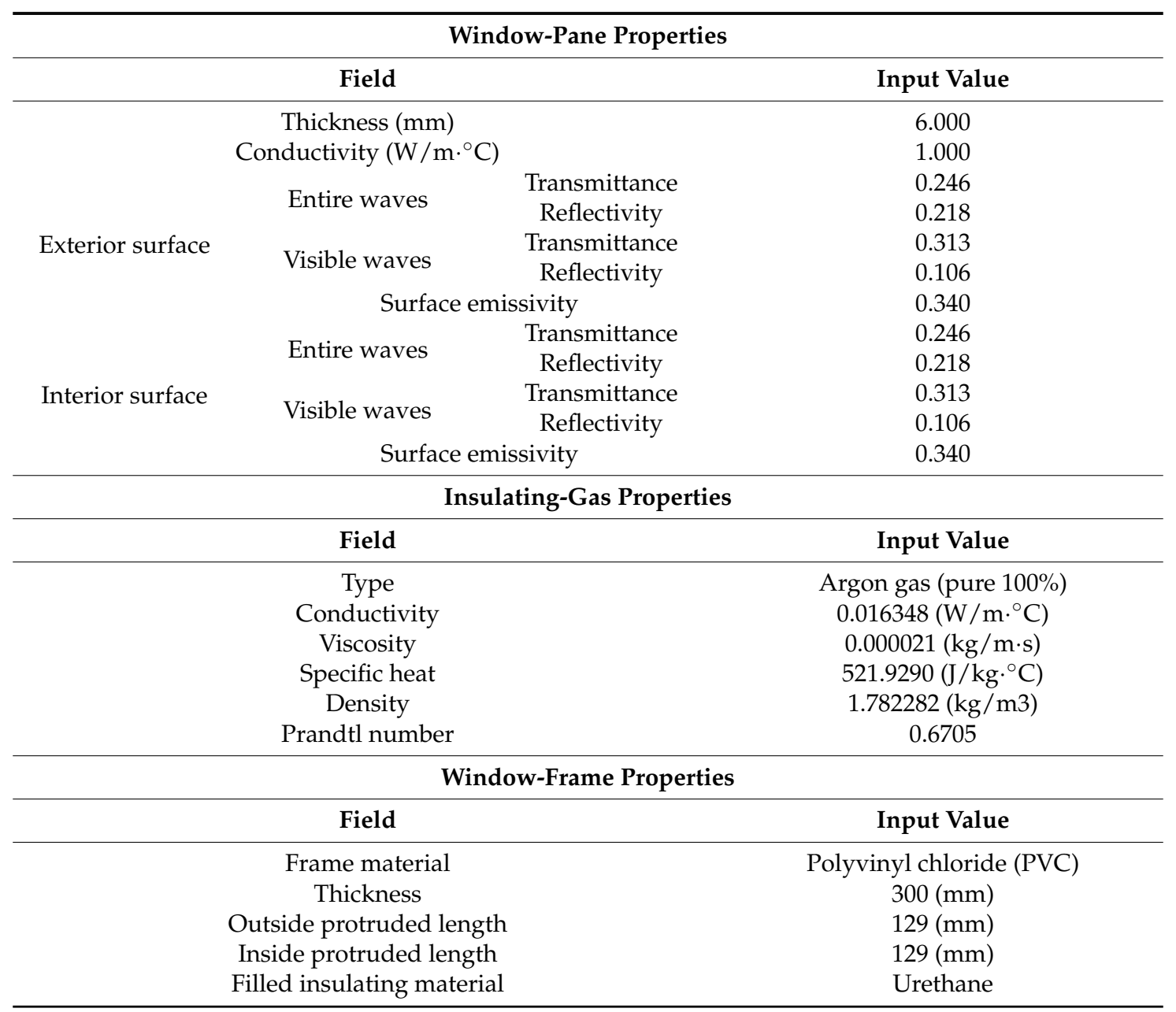


U-values of the said triple-pane windows were obtained based on properties of the above-listed constituent elements, as given in Table 5. The total pane and gas-layer thicknesses measured 18 and $24 \mathrm{~mm}$, respectively. The thickness of the spacer, which was composed of aluminum infused with a desiccant, installed between the panes measured $12 \mathrm{~mm}$-identical to that of the gas layer. The total thickness of the glazing system, including the panes, gas layers, and spacers, measured $42 \mathrm{~mm}$, and the total thickness of the frame equaled $300 \mathrm{~mm}$. To calculate the overall U-value, surface heat-transfer coefficients of 23.3 and $9.1 \mathrm{~W} / \mathrm{m}^{2} .{ }^{\circ} \mathrm{C}$ were applied to reflect domestic standards for indoor and outdoor temperatures of 20 and $0{ }^{\circ} \mathrm{C}$, respectively [31,34]. The resulting $\mathrm{U}$-value of the triple-pane window under these conditions was determined to be $1.101 \mathrm{~W} / \mathrm{m}^{2} \cdot{ }^{\circ} \mathrm{C}$.

Table 5. Heat transmittance of the triple-pane window (U-value).

\begin{tabular}{ccc}
\hline Type of System & Field & Input Value \\
\hline \multirow{3}{*}{ Glazing system } & $\begin{array}{c}\text { Total pane thickness } \\
(6+6 \mathrm{~mm})\end{array}$ & $18(\mathrm{~mm})$ \\
\cline { 2 - 3 } & $\begin{array}{c}\text { Total gas layers thickness } \\
(12+12 \mathrm{~mm})\end{array}$ & $24(\mathrm{~mm})$ \\
\cline { 2 - 3 } & $\begin{array}{c}\text { Spacer type } \\
(12+12 \mathrm{~mm})\end{array}$ & Aluminum spacer with desiccant \\
\cline { 2 - 3 } & Total glazing thickness & $42(\mathrm{~mm})$ \\
\hline Frame system & Total frame thickness & $300(\mathrm{~mm})$ \\
\hline \multirow{2}{*}{ Triple pane window } & Thermal transmittance $(\mathrm{U}-$ Value $)$ & $1.101\left(\mathrm{~W} / \mathrm{m}^{2} \cdot{ }^{\circ} \mathrm{C}\right)$ \\
& Domestic standard & $1.200\left(\mathrm{~W} / \mathrm{m}^{2} \cdot{ }^{\circ} \mathrm{C}\right)$ \\
\hline
\end{tabular}

\subsubsection{Phase Change Material}

The PCM inserted into the floor structure of the second story was of the solid-liquid type that undergoes phase change via latent heat exchange, which occurs within the temperature range $39-42{ }^{\circ} \mathrm{C}$ [35]. As depicted in Figure 9, modeling of the inserted PCM in EnergyPlus required the heat-storage capacities to be input corresponding to 15 temperatures, including those lying within the sensible- and latent-heat-exchange temperature ranges of the PCM. Within the $34-38^{\circ} \mathrm{C}$ range, the PCM demonstrated solid-state sensible heat exchange, wherein the temperature changes were observed. The corresponding heat-storage capacity within this temperature range equaled $3-9 \mathrm{~kJ} / \mathrm{kg}$. In contrast, the heat storage capacity in the $39-42{ }^{\circ} \mathrm{C}$ temperature range, wherein the PCM demonstrated phase change from solid to liquid, assumed values in the range of $22-37 \mathrm{~kJ} / \mathrm{kg}$. The temperature range to which the PCM demonstrated maximum heat storage was observed to be $41-42{ }^{\circ} \mathrm{C}$, above which the heat-storage capacity plummeted to only $2 \mathrm{~kJ} / \mathrm{kg}$, and the system became stable in the fully liquid state.

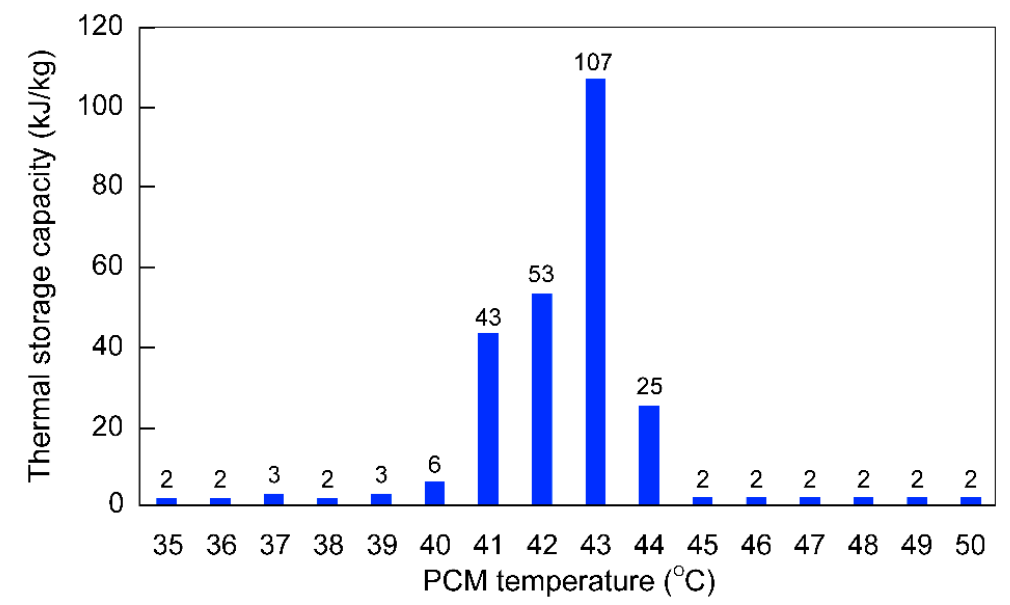

Figure 9. Variation in the heat-storage capacity of the PCM with change in temperature. 


\subsubsection{Indoor Heat-Gain and Heat-Loss Elements}

Figure 10 depicts schedules of indoor heat gain and loss elements employed in simulations performed in this study. These schedules corresponded to a resident family of four-the most common number of family members in domestic Korean households [36]. The occupancy time considered was between 18:00 $\mathrm{h}$ and 08:00 $\mathrm{h}$ the following day, and it was assumed that no occupants were present within the house at other times.

A ventilation rate of 0.5 air change per hour was used based on the domestic standard "Rules for Building Equipment Standards" [16]. In accordance with "Building Airtightness Criteria," domestic buildings, based on their infiltration rates, are classified as general buildings (5.0 air change per hour or lower), energy-saving buildings (3.0 air change per hour or lower), and zero-energy buildings (1.0 air change per hour or lower) [37]. The simulated apartment housing was assumed to be of the energy-saving building type with a target ventilation rate of 3.0 air change per hour.

EnergyPlus models light operation using a number between 0 and 1 to reflect occupant activity. The maximum value of 1 was applied between 18:00 $\mathrm{h}$ and 22:00 $\mathrm{h}$ as well as between 05:00 $\mathrm{h}$ and 08:00 $\mathrm{h}$, assuming these to be times of maximum occupant activity. A minimum value of 0.1 was applied between 22:00 $\mathrm{h}$ and 05:00 $\mathrm{h}$ to reflect sleep periods. No lighting was used between 08:00 $\mathrm{h}$ and 18:00 h, as no occupants were assumed to be present during this period.

The heat gains caused by human presence and the operation of electric equipment were excluded from the simulation, as these do not cast a significant effect on the heating load in a four-person occupied apartment.
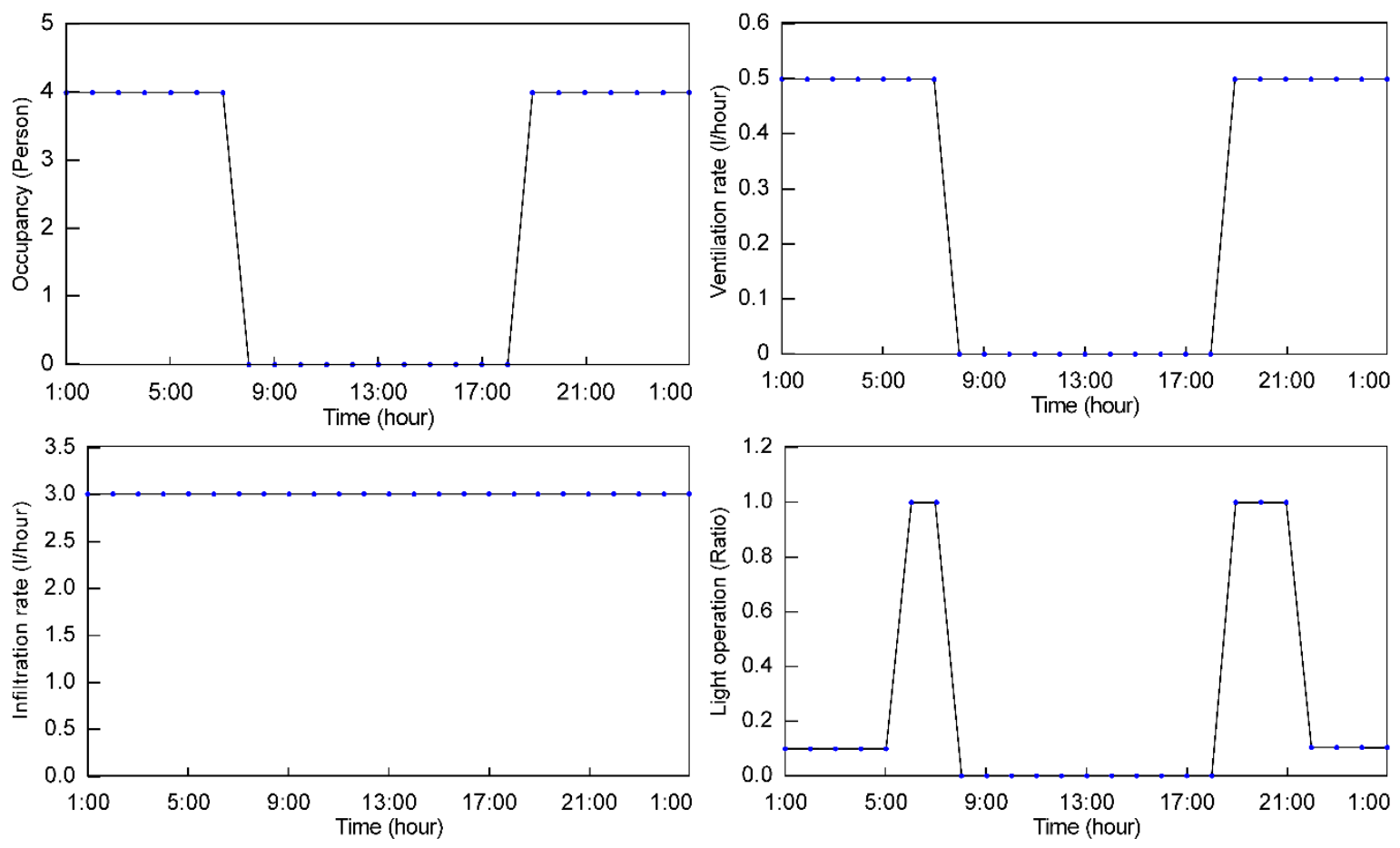

Figure 10. Daily schedules of heat loss and gain factors.

\subsubsection{District Heating}

District heating was employed as the heat-source supply system for the proposed PCM radiant floor-heating system. Figure 11 depicts a conceptual diagram of hot-water circulation via direct supply method, as applied during simulations performed in this study.

When supplied to the building, high-temperature hot water produced by a district heating plant is converted into mid-temperature hot water by means of a heat exchange unit and subsequently returned to the plant. The unit also converts low-temperature hot water obtained from the building to 
mid-temperature hot water, and resupplies it to the building. During the heating period, hot water is circulated via repeated transfers between the district heating plant and apartment building.

In accordance with domestic standards, supply and return temperatures of hot water from and to the district heating plant (supply side) equal 115 and $55^{\circ} \mathrm{C}$, respectively. Corresponding supply and return temperatures for an apartment building (demand side) equal 60 and $45^{\circ} \mathrm{C}$, respectively $[24,25]$. However, because the second-floor PCM radiant floor-heating system possesses structural and thermal characteristics that differ from those of conventional systems, it was deemed inappropriate to consider the said standard supply and return temperatures for use in this study, and therefore, new PCM floor-heating hot-water temperatures had to be investigated.

To accomplish this objective, results concerning various values of building hot-water supply and return temperatures were modeled against constant district heating plant supply and return temperatures of 115 and $55^{\circ} \mathrm{C}$, respectively. The supply temperature was sequentially decreased in steps of $1{ }^{\circ} \mathrm{C}$, from the conventional temperature of $60{ }^{\circ} \mathrm{C}$, until the floor-surface and indoor-air temperatures attained the pre-set value; the return temperature was then calculated by the flow controller, considering changes in the floor-surface temperature as well as the indoor and outdoor temperatures.

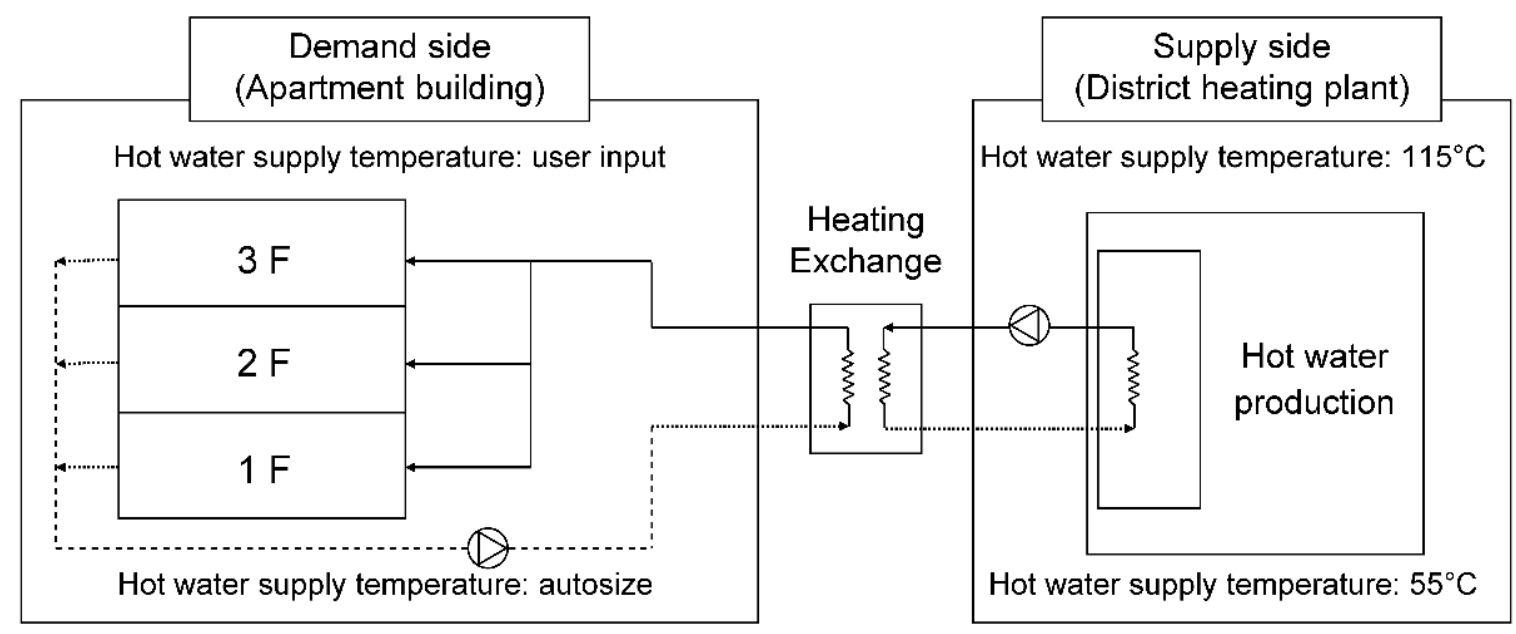

Figure 11. Conceptual schematic of the district heating hot-water circulation.

Table 6 lists the components used to connect the apartment housing and district heating plant in the EnergyPlus model. The district heating plant used hot water as a heat source, and possessed a maximum plant capacity of $1 \mathrm{MW}$ to ensure the supply of a sufficient amount of hot water. An insulation condition with no heat loss from the surface was considered for all pipes.

Devices used for district heating within the apartment included a hydronic pump, a hot-water pipe, and a bypass. The pipe connected to the hydronic pump measured $15 \mathrm{~mm}$ in internal diameter, and a pump head pressure of $200 \mathrm{kPa}$ was used to ensure that the hot water reached the third story of the building. A maximum motor efficiency of $90 \%$ was considered along with an intermittent pump control assembly, to automatically control the flow rate of hot water in accordance with the floor-surface and indoor-air temperatures. The hot-water pipe was assumed to incur no heat loss. The internal diameter and heat loss of the bypass were set to be identical to those of the hot-water pipe.

\subsubsection{Heating Operation Conditions}

Based on domestic regulations and the results reported in extant studies [31,38], floor-surface and indoor-air temperatures of the apartment housing were set to 22 and $30{ }^{\circ} \mathrm{C}$, respectively.

As described in Section 2.2.5, heating hours corresponded to the duration between 18:00 $\mathrm{h}$ to 08:00 $\mathrm{h}$ the following day, during which no occupants were assumed present inside the house, whereas non-heating hours corresponded to $08: 00 \mathrm{~h}$ to 18:00 $\mathrm{h}$ (Figure 12). The non-heating hours 
were set such that the floor-surface and indoor-air temperatures would not drop below 5 and $10^{\circ} \mathrm{C}$, respectively.

Table 6. District heating components.

\begin{tabular}{|c|c|c|c|}
\hline Loop Type & \multicolumn{2}{|c|}{ Field } & Input Value \\
\hline \multirow{3}{*}{ District heating plant loop } & \multicolumn{2}{|c|}{ Heating source } & Hot water \\
\hline & \multicolumn{2}{|c|}{ Heating capacity } & $1(\mathrm{MW})$ \\
\hline & \multicolumn{2}{|c|}{ Maximum flow rate } & Autosize $\left(\mathrm{m}^{3} / \mathrm{s}\right)$ \\
\hline \multirow{3}{*}{ Apartment housing loop } & Hydronic Pump & $\begin{array}{l}\text { Pipe inside diameter } \\
\text { Maximum flow rate } \\
\text { Head pressure } \\
\text { Motor efficiency } \\
\text { Control type }\end{array}$ & $\begin{array}{c}0.015(\mathrm{~m}) \\
\text { Autosize }\left(\mathrm{m}^{3} / \mathrm{s}\right) \\
200(\mathrm{kPa}) \\
0.9 \\
\text { Intermittent }\end{array}$ \\
\hline & Hot-water pipe & $\begin{array}{l}\text { Inside diameter } \\
\text { Heat loss }\end{array}$ & $\begin{array}{l}0.015(\mathrm{~m}) \\
\text { Adiabatic }\end{array}$ \\
\hline & Bypass & $\begin{array}{c}\text { Inside diameter } \\
\text { Heat loss }\end{array}$ & $\begin{array}{l}0.015(\mathrm{~m}) \\
\text { Adiabatic }\end{array}$ \\
\hline
\end{tabular}

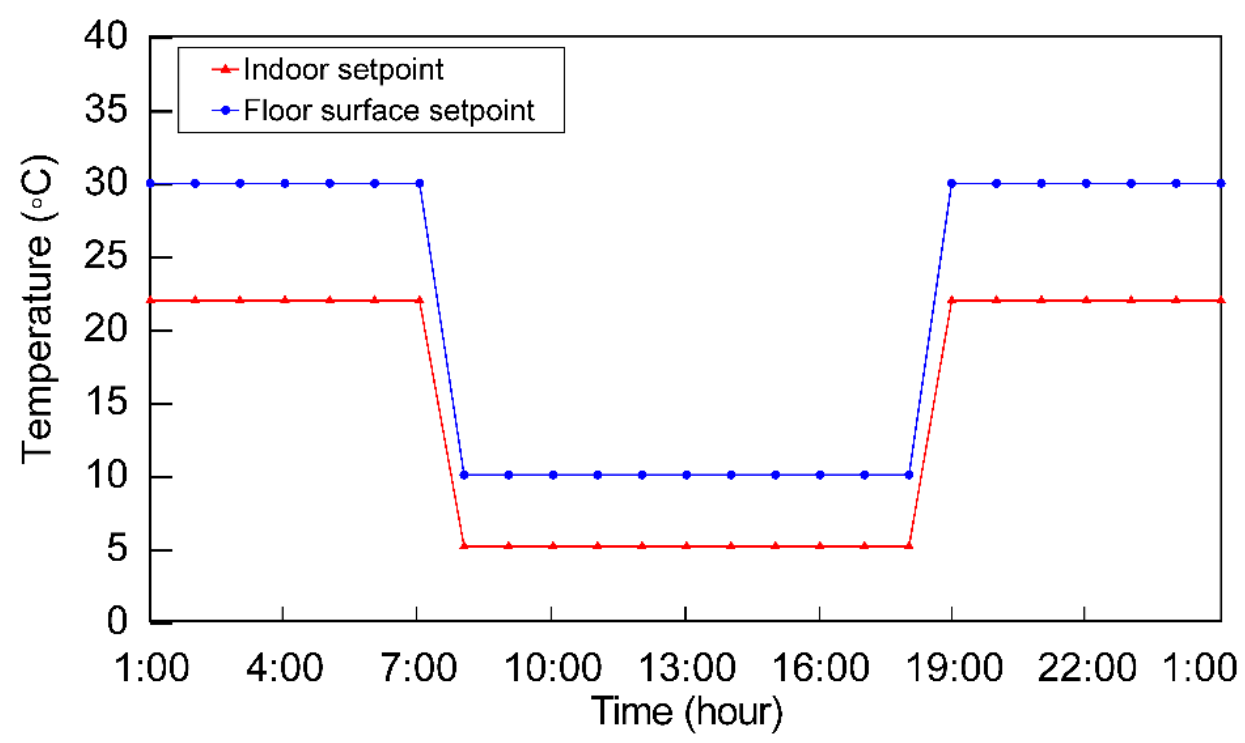

Figure 12. Floor-surface and indoor-air temperature schedules.

\section{Results and Discussion}

The scope of the analysis was limited to the second story, wherein the proposed PCM radiant floor-heating system was installed. Simulations were performed for the period between 26 and 28 January, during which the outdoor temperature typically attains its lowest annual value. All conditions, including the building structure as well as the indoor and outdoor environment, were kept constant while reducing the hot-water supply temperature from $60^{\circ} \mathrm{C}$ in steps of $1{ }^{\circ} \mathrm{C}$.

\subsection{Hot-Water Supply Temperature}

Figure 13 depicts the hourly variation in floor-surface temperatures, at various hot-water supply temperatures, lying within the range $38-43{ }^{\circ} \mathrm{C}$. In each case, following heating at 18:00 $\mathrm{h}$, the floor-surface temperature attained a stable state (represented by nearly straight-line segments in the diagram) at approximately 21:00 h. The period between 18:00 $\mathrm{h}$ and 21:00 $\mathrm{h}$ can, therefore, be considered as the preheating time during which the floor-surface temperature remains unstable. Consequently, the actual period of surface-temperature analysis was from 21:00 $\mathrm{h}$ on 26 January to 
08:00 h on 27 January and from 21:00 h on 27 January to $08: 00 \mathrm{~h}$ on 28 January, during which the floor-surface temperature remained nearly constant.

At a hot-water supply temperature of $38^{\circ} \mathrm{C}$, the floor-surface temperature was observed to be in the range $28-28.5^{\circ} \mathrm{C}$ during the period from $21: 00 \mathrm{~h}$ on 26 January to $08: 00 \mathrm{~h}$ on 27 January. Correspondingly, between $21: 00 \mathrm{~h}$ on 27 January and 08:00 $\mathrm{h}$ on 28 January, the floor-surface temperature measured in the range $28.1-28.4{ }^{\circ} \mathrm{C}$. During the entire simulation period at the said hot-water temperature, the floor-surface temperature was observed to measure less than the pre-set value of $30^{\circ} \mathrm{C}$ by $1.5-2.0^{\circ} \mathrm{C}$.

At a hot-water supply temperature of $39^{\circ} \mathrm{C}$, the floor-surface temperature measured $28.2-29.2^{\circ} \mathrm{C}$ during the period from 21:00 $\mathrm{h}$ on 26 January to $08: 00 \mathrm{~h}$ on 27 January. Correspondingly, between 21:00 $\mathrm{h}$ on 27 January and 08:00 $\mathrm{h}$ on 28 January, the floor-surface temperature measured in the range 28.3-29. $1^{\circ} \mathrm{C}$. Consequently, during the entire simulation period the floor-surface temperature measured $0.8-1.8^{\circ} \mathrm{C}$ lower than the corresponding pre-set value.

At a hot-water supply temperature of $40{ }^{\circ} \mathrm{C}$, the floor-surface temperature measured $28.8-29.9^{\circ} \mathrm{C}$ during the period from 21:00 $\mathrm{h}$ on 26 January to $08: 00 \mathrm{~h}$ on 27 January. Correspondingly, between 21:00 $\mathrm{h}$ on 27 January and $08: 00 \mathrm{~h}$ on 28 January, the floor-surface temperature measured in the range $28.8-29.8^{\circ} \mathrm{C}$. In particular, the floor-surface temperature measured in the range $28.8-29.3^{\circ} \mathrm{C}$ - slightly lower than the pre-set value- between 21:00 $\mathrm{h}$ and 23:00 $\mathrm{h}$. However, after 23:00 $\mathrm{h}$, the floor-surface temperature measured $29.6-29.9^{\circ} \mathrm{C}$, which was very close to (within $0.1-0.4{ }^{\circ} \mathrm{C}$ of) the pre-set temperature.

At a hot water supply temperature of $41^{\circ} \mathrm{C}$, the floor-surface temperature measured in the range 29.2-30. $6^{\circ} \mathrm{C}$ between 21:00 $\mathrm{h}$ on 26 January and $08: 00 \mathrm{~h}$ on 27 January; correspondingly, the floor-surface temperature measured $29.4-30.5^{\circ} \mathrm{C}$ between $21: 00 \mathrm{~h}$ on 27 January and $08: 00 \mathrm{~h}$ on 28 January. Although during certain hours the floor-surface temperature exceeded the pre-set value (by roughly $0.5-0.6^{\circ} \mathrm{C}$ ), the floor-surface temperature, for the most part, measured very close to the pre-set value (within $\left.0.5^{\circ} \mathrm{C}\right)$.

At a hot-water supply temperature of $42{ }^{\circ} \mathrm{C}$, the floor-surface temperature measured in the range 29.8-31. $3^{\circ} \mathrm{C}$ between $21: 00 \mathrm{~h}$ on 26 January and $08: 00 \mathrm{~h}$ on 27 January; correspondingly, the floor-surface temperature measured $29.9-31.2{ }^{\circ} \mathrm{C}$ between $08: 00 \mathrm{~h}$ on 27 January to $08: 00 \mathrm{~h}$ on 28 January. In general, after 21:00 $\mathrm{h}$, the floor-surface temperature was observed to exceed its pre-set value by $0.5-1.3^{\circ} \mathrm{C}$.

At a hot-water supply temperature of $43^{\circ} \mathrm{C}$, the floor-surface temperature measured in the range $30.5-32.0^{\circ} \mathrm{C}$ between $21: 00 \mathrm{~h}$ on 26 January and $08: 00 \mathrm{~h}$ on 27 January; correspondingly, the floor-surface temperature measured $30.5-31.9^{\circ} \mathrm{C}$ between $18: 00 \mathrm{~h}$ on 27 January and 08:00 $\mathrm{h}$ on 28 January. In this case, the floor-surface temperature was observed to be quite different from its pre-set value at all times.

In terms of the average temperature, at all heating times excluding the preheating hours, the average temperature of the floor surface measured 28.2, 28.9, 29.6, 30.2, 30.9, and $31.6{ }^{\circ} \mathrm{C}$ corresponding to hot-water supply temperatures of $38,39,40,41,42$, and $43{ }^{\circ} \mathrm{C}$, respectively. At supply temperatures of 38 and $39^{\circ} \mathrm{C}$, the floor-surface temperature did not attain its pre-set value, whereas at supply temperatures of 42 and $43^{\circ} \mathrm{C}$, the floor-surface temperature measured higher compared to its pre-set value. However, at supply temperatures of 40 and $41{ }^{\circ} \mathrm{C}$, the floor-surface temperature consistently measured close to its pre-set value.

In summary, supplying hot water at or below $39^{\circ} \mathrm{C}$ to the radiant floor-heating system resulted in a floor-surface temperature below it pre-set value of $30^{\circ} \mathrm{C}$, corresponding to the PCM that undergoes phase change above $39^{\circ} \mathrm{C}$. This causes the PCM to either remain solid in the cooling state or to fail to undergo full liquefaction. Under this condition, occupants may feel discomfort owing to a low floor-surface temperature, and the energy saving effect might not be realized as the latent heat of the PCM can no longer be utilized.

On the other hand, supplying hot water at $42{ }^{\circ} \mathrm{C}$ or higher leads to situations wherein the floor surface could overheat, thereby resulting in supply of unnecessary thermal energy to the indoor space and potential liquefaction of PCM beyond latent heat exchange. In addition to increasing the room temperature beyond an unnecessary level, such overheating could lead to structural problems caused 
by the generation of fine cracks within the ALC and mortar surrounding the PCM container, owing to increased pressure and volume within the container.

The above results suggest that the most appropriate hot-water supply temperature for radiant floor-heating systems, installed with a $10 \mathrm{~mm}$ thick PCM layer, lies in the range $40-41{ }^{\circ} \mathrm{C}$. By maintaining the supply temperature within this range, the latent heat exchange of the PCM can be appropriately utilized, and the floor-surface temperature can be maintained at its pre-set value.

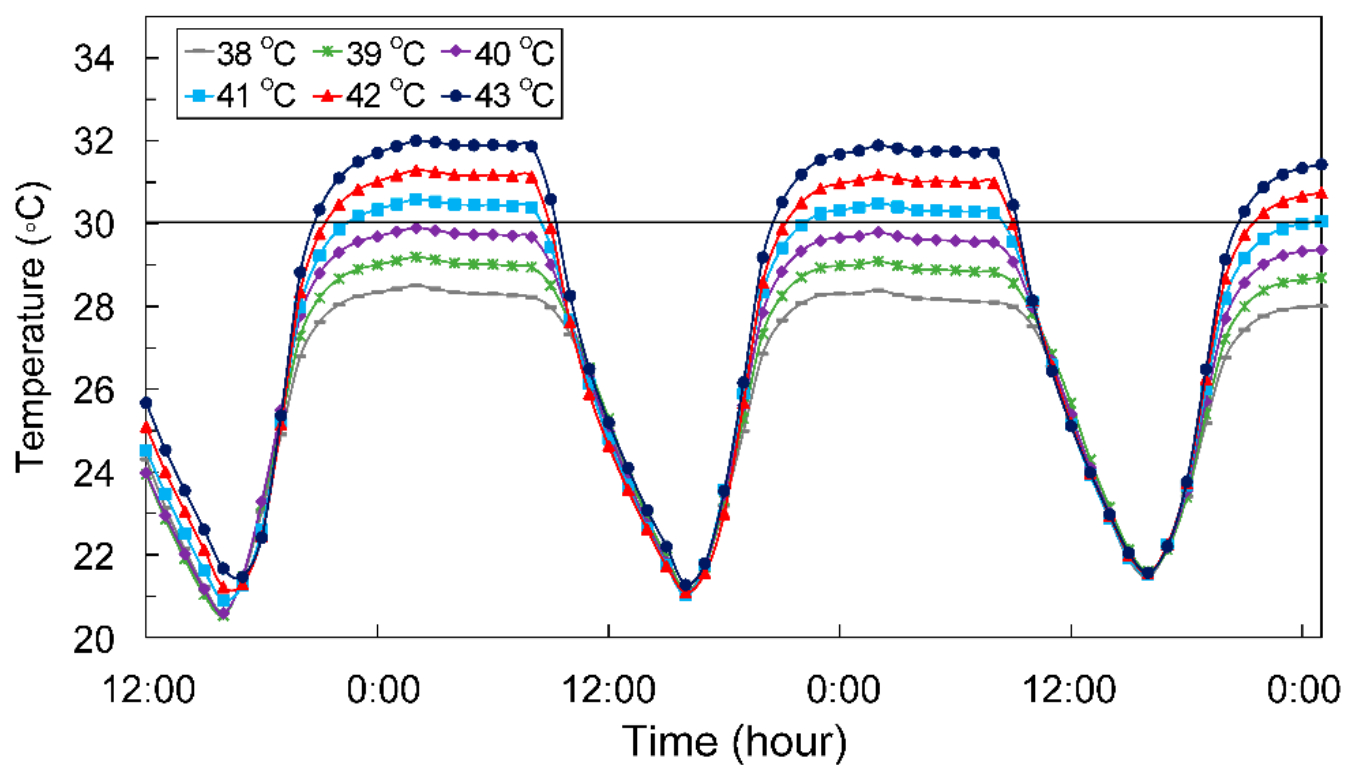

Figure 13. Hourly variations in the floor-surface temperature with differing supply temperatures.

\subsection{Return Temperature of Hot Water}

Figure 14 depicts hourly variations in the return temperatures of hot water supplied at 40 and $41^{\circ} \mathrm{C}$ to the PCM radiant floor-heating system between 26 and 28 January.

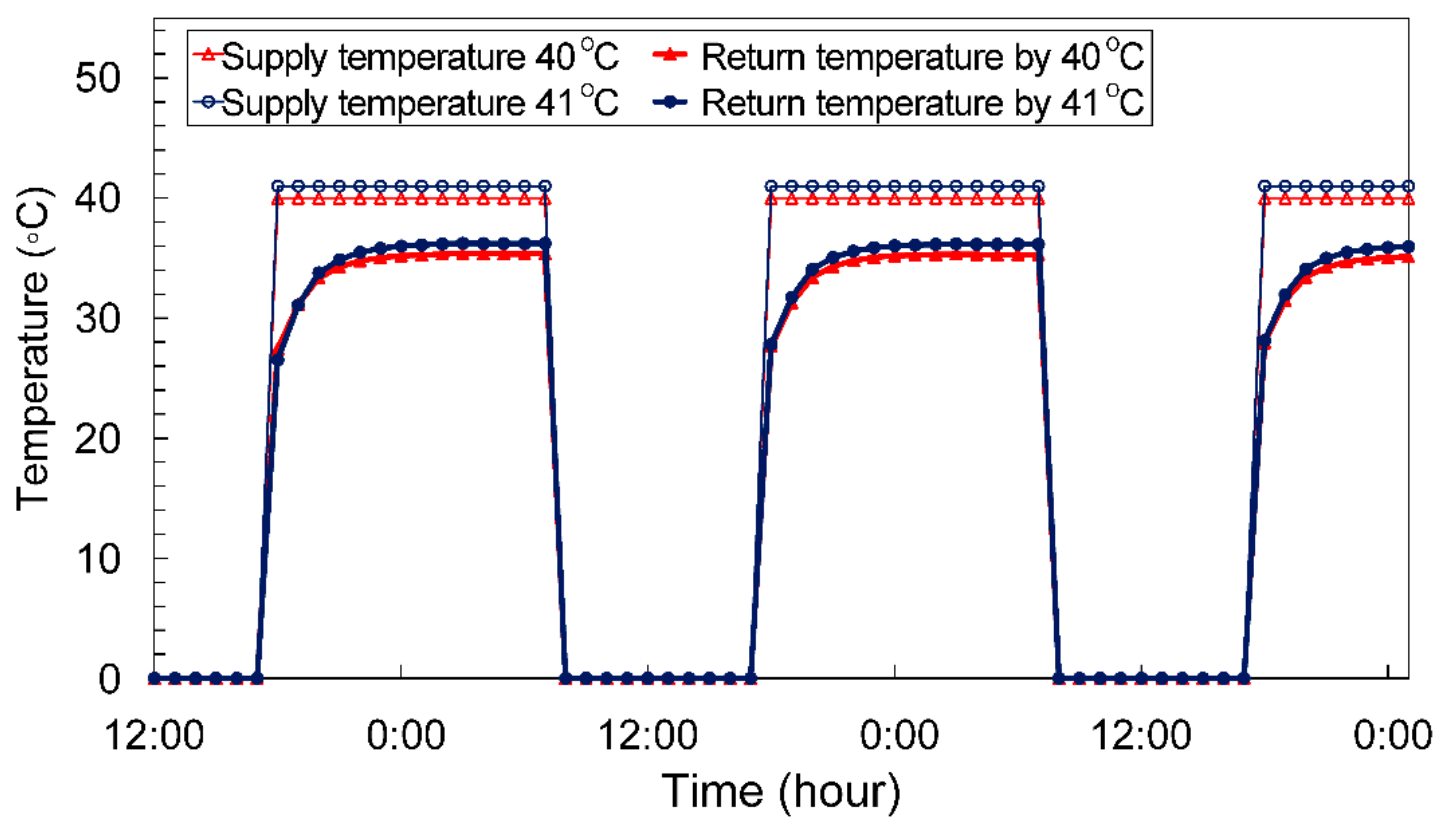

Figure 14. Hourly variations in the return temperatures with differing supply temperatures.

At the hot-water supply temperature of $40{ }^{\circ} \mathrm{C}$, the corresponding return temperature measured in the range $27.4-35.4{ }^{\circ} \mathrm{C}$ between $18: 00 \mathrm{~h}$ on 26 January and $08: 00 \mathrm{~h}$ on 27 January; correspondingly, 
the return temperature measured $27.6-35.3^{\circ} \mathrm{C}$ between $18: 00 \mathrm{~h}$ on 27 January and $08: 00 \mathrm{~h}$ on 28 January. The return temperature measured the lowest between 18:00 $\mathrm{h}$ and 21:00 $\mathrm{h}$ because a large quantity of thermal energy had to be supplied to raise the temperature of the floor-which had cooled during the non-heating hours-up to the pre-set value. In contrast, after 21:00 $\mathrm{h}$, the return temperature remained approximately constant, as the floor-surface temperature had nearly attained the pre-set temperature. This result suggests an optimum return-temperature value of $27.4{ }^{\circ} \mathrm{C}$, the lowest value measured over the course of the simulation.

At a hot-water supply temperature of approximately $41{ }^{\circ} \mathrm{C}$, the return temperature measured in the range $27.5-36.2^{\circ} \mathrm{C}$ between $18: 00 \mathrm{~h}$ on 26 January and $08: 00 \mathrm{~h}$ on 27 January; correspondingly, the return temperature measured $27.8-36.2^{\circ} \mathrm{C}$ between $18: 00 \mathrm{~h}$ on 27 January and $08: 00 \mathrm{~h}$ on 28 January. Thus, a pattern similar to that observed at a hot-water supply temperature of $40{ }^{\circ} \mathrm{C}$ was observed. That is, the return temperature remained nearly constant in the range $27.5-36.2^{\circ} \mathrm{C}$ across heating hours. This suggests an optimal return-temperature value of $27.5^{\circ} \mathrm{C}$ for the hot-water supply at $41^{\circ} \mathrm{C}$.

\subsection{Indoor-Air Temperature}

Figure 15 depicts hourly variations in the indoor-air temperatures corresponding to hot-water supply and return temperatures in the range $40-41{ }^{\circ} \mathrm{C}$ and $27.4-27.5^{\circ} \mathrm{C}$, respectively, in the PCM radiant floor-heating system during the period from 26-28 January.

At hot-water supply and return temperatures of 40 and $27.4{ }^{\circ} \mathrm{C}$, respectively, the indoor-air temperature measured in the range $18.7-22^{\circ} \mathrm{C}$ between $18: 00 \mathrm{~h}$ on 26 January and $08: 00 \mathrm{~h}$ on 27 January; correspondingly, the return temperature measured $18.8-21.9^{\circ} \mathrm{C}$ between 18:00 $\mathrm{h}$ on 27 January and 08:00 h on 28 January. Excluding preheating hours from 18:00 to 22:00 h, based on above results, the indoor-air temperature was observed to fall within the range $21.6-22.1^{\circ} \mathrm{C}$ (i.e., within $0.1-0.6{ }^{\circ} \mathrm{C}$ of its pre-set value of $22{ }^{\circ} \mathrm{C}$ ). The indoor-air temperature was stabilized approximately one hour after the floor-surface temperature, thereby apparently reflecting the time needed for heat to be transferred from the floor-surface to the indoor space.

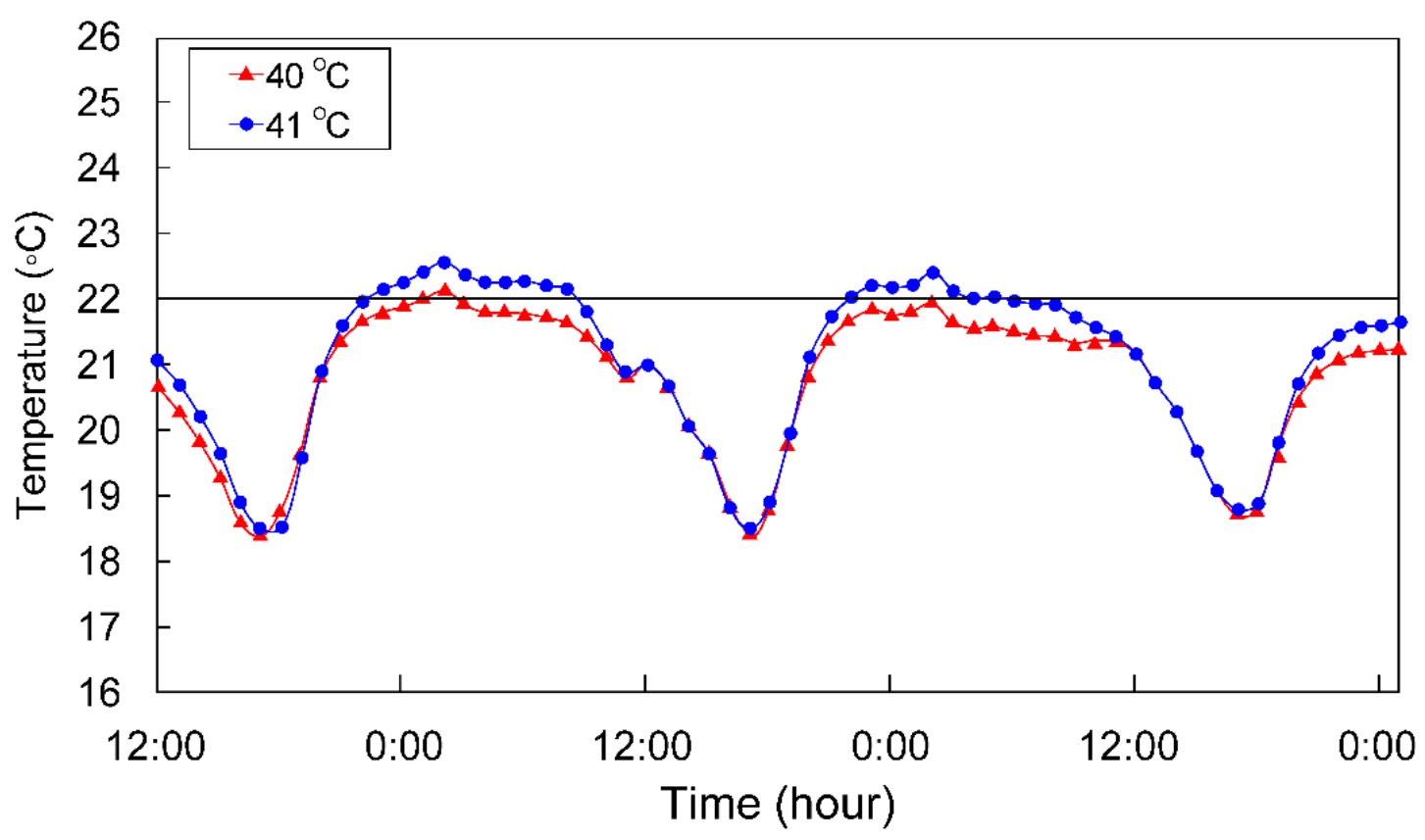

Figure 15. Hourly variations in the indoor-air temperature with differing supply temperatures.

At supply and return temperatures of 41 and $27.5^{\circ} \mathrm{C}$, respectively, the indoor-air temperature outside of preheating hours measured in the range $22.0-22.6^{\circ} \mathrm{C}$ between $22: 00 \mathrm{~h}$ on 26 January and 08:00 $\mathrm{h}$ on 27 January; correspondingly, the return temperature measured $22.1-22.4{ }^{\circ} \mathrm{C}$ between $22: 00 \mathrm{~h}$ on 27 January and 08:00 $\mathrm{h}$ on 28 January. Under these hot-water conditions, the indoor-air temperature 
followed a pattern similar to that observed for supply and return temperatures of 40 and $27.4{ }^{\circ} \mathrm{C}$, respectively, and remained within $0.1-0.6{ }^{\circ} \mathrm{C}$ of the $22{ }^{\circ} \mathrm{C}$ pre-set value.

In summary, outside of the preheating hours (18:00-22:00 h), setting the hot-water supply and return temperatures in the range $40-41^{\circ} \mathrm{C}$ and $27.4-27.5^{\circ} \mathrm{C}$, respectively, resulted in steady maintenance of the indoor-air temperature within $0.1-0.6^{\circ} \mathrm{C}$ of the $22^{\circ} \mathrm{C}$ pre-set value.

\section{Conclusions}

The proposed study determines optimum hot-water supply and return temperatures for a PCM radiant floor-heating system. To this end, computer simulations were performed to derive hot-water supply and return temperatures that could stably maintain floor-surface and indoor-air temperatures, close to their respective pre-set values, through use of the latent heat of the PCM during the coldest period of outdoor temperatures. Results of this study are summarized hereunder.

(1) The optimum hot-water supply temperature, for maintaining floor-surface and indoor-air temperatures close to their pre-set values using a wet-constructed PCM radiant floor-heating system containing a $10 \mathrm{~mm}$ thick PCM layer, lies in the range $40-41{ }^{\circ} \mathrm{C}$. If hot water is supplied at or below $39{ }^{\circ} \mathrm{C}$ or at or above $42{ }^{\circ} \mathrm{C}$, the floor-surface temperature cannot be maintained at its pre-set value, and the latent heat of the PCM cannot be effectively utilized, thereby resulting in the compromised energy-saving capability of the proposed system.

(2) The optimum hot-water return temperature under very cold conditions (i.e., at minimum annual temperatures) was determined to be the lowest temperature of hot-water returned from the floor during heating hours. Simulations were performed corresponding to hot-water supply and return temperatures in the range $40-41{ }^{\circ} \mathrm{C}$ and $27.4-27.5^{\circ} \mathrm{C}$, respectively. However, it should be noted that the difference between the two hot-water supply temperatures was only $1{ }^{\circ} \mathrm{C}$ and, therefore, a minimum difference of $0.1^{\circ} \mathrm{C}$ in return temperatures should not be surprising.

(3) Under the supply and return temperature conditions described in (2), the system was analyzed to determine whether the indoor-air temperature attained its pre-set value of $22{ }^{\circ} \mathrm{C}$. As observed, the indoor-air temperature measured in the range $18.7-22.6^{\circ} \mathrm{C}$ during heating hours, and that when preheating hours were exchanged, the above range was narrowed down to $\pm 0.6^{\circ} \mathrm{C}$ around the pre-set value (i.e., the indoor-air temperature measured in the range $21.4-22.6^{\circ} \mathrm{C}$ ).

(4) The proposed radiant floor-heating system comprised a $10 \mathrm{~mm}$ thick PCM layer, concrete slabs, insulating material, ALC, and mortar. For floor structures and PCM thicknesses differing from these, processes and analysis techniques described in this study could be used as reference for determining corresponding optimum hot-water supply and return temperatures.

This study has been built upon extant work performed with regards to deriving an optimum design of a PCM radiant floor-heating system, with appropriate hot-water supply and return temperatures for maintaining the floor-surface and indoor-air temperatures at their respective pre-set values. When employing the actual system within the floor structure of an apartment building under such conditions, it will be necessary to examine how much energy saving can be realized relative to conventional systems. To do so, a follow-up study will be performed to compare the energy consumption of a conventional system against that of the proposed PCM radiant floor-heating system built in accordance with the wet construction method.

Author Contributions: Funding acquisition, S.K.; project administration, S.K.; writing-original draft, S.B.; writing一review \& editing, S.B. and S.K.

Funding: This research was supported by the Basic Science Research Program through the National Research Foundation of Korea (NRF), funded by the Ministry of Education (grant number: 2018R1D1A1B07048848).

Conflicts of Interest: The authors declare no conflict of interest. 


\section{References}

1. McMullan, R.Y. Environmental Science in Building; Rhee, U., Kim, K., Eds.; Tae Rim Publishing Inc.: Seoul, Korea, 1997; pp. 6-17.

2. Lin, K.; Zhang, Y.; Xu, X.; Di, H.; Yang, R.; Qin, P. Modeling and simulation of under-floor electric heating system with shape-stabilized PCM plates. Build. Environ. 2004, 39, 1427-1434. [CrossRef]

3. Lin, K.; Zhang, Y.; Di, H.; Yang, R. Study of an electrical heating system with ductless air supply \& shape-stabilized PCM for thermal storage. Energy Convers. Manag. 2007, 48, 2016-2024.

4. Jin, X.; Zhang, X. Thermal analysis of a double layer phase change material floor. Appl. Therm. Eng. 2011, 31, 1576-1581. [CrossRef]

5. Huang, K.; Feng, G.; Zhang, J. Experimental and numerical study on phase change material floor in solar water heating system with a new design. Sol. Energy 2014, 105, 126-138. [CrossRef]

6. Barzin, R.; Chen, J.J.J.; Young, R.B.; Farid, M.M. Application of PCM underfloor heating in combination with PCM wallboards for space heating using price based control system. Appl. Energy 2015, 148, 39-48. [CrossRef]

7. Cheng, W.; Xie, B.; Zhang, R.; Xu, Z.; Xia, Y. Effect of thermal conductivities of shape stabilized PCM on under-floor-heating system. Appl. Energy 2015, 144, 10-18. [CrossRef]

8. Zhou, G.; He, J. Thermal performance of a radiant floor-heating system with different heat storage materials and heating pipes. Appl. Energy 2015, 138, 648-660. [CrossRef]

9. Maria, T.; Christos, T.; Evangelos, B.; Kimon, A. Energetic investigation of solar assisted heat pump underfloor heating systems with and without phase change materials. Energy Convers. Manag. 2018, 173, 626-639.

10. Yeo, M.S.; Yang, I.H.; Kim, K.W. Historical changes and recent energy saving potential of residential heating in Korea. Energy Build. 2003, 35, 715-727. [CrossRef]

11. Kim, J.W. A study on the energy performance according to heating system in apartment housing. Master's Thesis, ChungAng Unversity, Seoul, Korea, 2013.

12. Baek, S.H.; Park, J.C. Performance of thermal storage mass with Phase Change Material in the under-floor-heating system. Archit. Inst. Korea 2016, 36, 509-510.

13. Baek, S.H.; Park, J.C. Proposal of a PCM underfloor-heating system using a wet construction method. Int. J. Polym. Sci. 2017, 2017, 1-10. [CrossRef]

14. Baek, S.H.; Yoon, S.G.; Park, J.C. Analysis on Effects of Melting Points to apply to PCMs in Radiant Floor-heating systems using Wet Construction and Hot Water. Korean Soc. Living Environ. Syst. 2018, 25, 1-6. [CrossRef]

15. Thomson Reuters LAWnB. Standard of Impact Sound Insulation Structure for Preventing Noise between Floors. Available online: http:/ / www.lawnb.com/Info/ContentView?sid=L006A907EBEE7A64 (accessed on 20 July 2018).

16. Thomson Reuters LAWnB. Rules for Building Equipment Standards. Available online: http:/ /www.lawnb. com/Info/ContentView?sid=L000E49C14015A53 (accessed on 20 July 2018).

17. Thomson Reuters LAWnB. Rules for Ranges and Standards of Noise between Floors in Apartment Housing. Available online: http:/ /www.lawnb.com/Info/ContentView?sid=L000D15D0FD38912_0 (accessed on 20 July 2018).

18. Cho, D.W.; Yu, K.H. Optimal design process of Ondol heating system in apartment houses. Soc. Air-Cond. Refrig. Eng. Korea 2011, 7, 521-526.

19. Yun, C.Y.; Jeong, J.H.; Kim, M.J. The Effect of Aerated Concrete containing Foam Glass Aggregate on the Floor Impact Sound Insulation. Korean Soc. Noise Vib. Eng. 2013, 23, 414-422. [CrossRef]

20. Lee, S.H.; Jeong, G.C. A Plan to guarantee quality of Light-weight Cellular Concrete for floating floor. Korean Soc. Noise Vib. Eng. 2003, 11, 938-943.

21. Kim, S.Y.; Ko, E.H.; Jeon, B.M.; Oh, S.G. Development of the Hardened Lightweight Cement Using the Polyethylene Tube. Reg. Assoc. Archit. Inst. Korea 2006, 2, 423-428.

22. Nam, D.H.; Shin, Y.H.; Kim, K.J.; Kim, M.B. A Study on Determination of Damping Layer Thickness to Reduce Heavy Impact Noise in Apartment building Floors. Korean Soc. Noise Vib. Eng. 2005, 11, 936-941.

23. Phase Change Material (PCM) in the Assembly Line (YouTube Video). Available online: https://www. youtube.com/watch?v=3x7DEyqXuqA (accessed on 20 July 2018). 
24. Korea District Heating Corporation. Rules for Heat Energy Supply. Available online: https://www.kdhc.co. $\mathrm{kr} /$ content.do?cmsCd=CM3857\#section3 (accessed on 20 July 2018).

25. Jung, Y.H. An Analysis on the Heating Load and Supply Water Temperature for Direct Connection in District Heating System. J. Korean Inst. Archit. Sustain. Environ. Build. Syst. 2010, 4, 165-173.

26. U.S. Department of Energy. EnergyPlus Version 8.7.0. Documentation: Getting Started. Available online: https: / / energyplus.net/documentation (accessed on 20 July 2018).

27. U.S. Department of Energy. EnergyPlus Version 8.7.0. Documentation: Input Output Reference. Available online: https:/ / energyplus.net/documentation (accessed on 20 July 2018).

28. U.S. Department of Energy. EnergyPlus Version 8.7.0. Documentation: Engineering Reference. Available online: https:/ / energyplus.net/documentation (accessed on 20 July 2018).

29. The Korean Solar Energy Society. Korea Standard Weather Data: Seoul. Available online: http://www.kses. re.kr/data_06/list_hi.php (accessed on 20 July 2018).

30. Cengel, Y.A. Natural convection. In Introduction to Thermodynamics \& Heat Transfer; Kwon, O.B., Kim, E.P., Bae, D.S., Kim, T.K., Eom, Y.K., Lee, D.H., Lim, K.B., Eds.; Inter Vision Publishing Inc.: Seoul, Korea, 2006.

31. Thomson Reuters LAWnB. Standard for Energy Saving Design of Building. Available online: http:/ / www. lawnb.com/Info/ContentView?sid=L0064E3F5D588CDE (accessed on 20 July 2018).

32. Carli Inc. Conrad 5 \& Viewer 5 Technical and Programming Documentation. Available online: https: / / windows.lbl.gov/sites/all/ files/Downloads/conrad-and-viewer-06-20-06.pdf (accessed on 20 July 2018).

33. National Fenestration Rating Council, Inc. Therm $7 /$ Window 7 NFRC Simulation Manual. Available online: https:/ / cdn.ymaws.com/www.nfrccommunity.org/resource/resmgr/2017_Tech_Docs/ NFRCSim7-July2017.pdf (accessed on 20 July 2018).

34. Korean Standards Service Network. Standard Test Method for Thermal Resistance for Windows and Doors. Available online: http:/ / www.kssn.net/StdKS/ks_detail.asp?k1=F\&k2=2278\&k3=7 (accessed on 20 July 2018).

35. Rubitherm Ltd. PCM RT-LINE, Product Tab. Available online: https://www.rubitherm.eu/en/ productCategories.html (accessed on 20 July 2018).

36. Korean Statistical Information Service. Population and Household Number. Available online: http:/ / kosis.kr/statisticsList/statisticsListIndex.do?menuId=M_01_01\&vwcd=MT_ZTITLE\&parmTabId= M_01_01\&statId=1962001\&themaId=A\#A1.2 (accessed on 20 July 2018).

37. Korean Institute of Architectural Sustainability Environment and Building System. Building Airtightness Critical. Available online: http:/ /www.kiaebs.org/html/sub08_1.jsp?ncode=a003 (accessed on 20 July 2018).

38. Tamura, A.; Yoon, C.S.; Fukai, K.; Chung, Y.S. A Comparative Study on Thermal Responses of Male and Female in Thermal Environmental Conditions in Floor-heating system. J. Archit. Inst. Korea 1999, 15, 127-134. 